\title{
PENGARUH KEMAMPUAN VULVA HYGIENE TERHADAP WAKTU PENYEMBUHAN LUKA PERINEUM PADA IBU POST PARTUM PRIMIPARA
}

\section{THE EFFECT OF THE ABILITY TIME OF VULVA HYGIENE ON THE HEALING TIME OF PERENNIAL WOUNDS IN PRIMIPAROUS POSTPARTUM MOTHERS}

\author{
Ponco Indah Arista Sari \\ STIKES Muhammadiyah Lamongan \\ Email : pindaharistaszulianto@gmail.com
}

\begin{abstract}
ABSTRAK
Vulva hygiene (care perineum) adalah tindakan untuk membersihkan dan menutrisi area kemaluan/kewanitaan pada wanita terutama postpartum cedera perineum. Tujuan dari penelitian ini adalah untuk mengetahui pengaruh kemampuan ibu terhadap kebersihan vulva terhadap penyembuhan luka perineum post partum waktu. Penelitian ini menggunakan metode studi korelasional, desain penelitian longitudinal prospektif (cohort). Sampel adalah semua ibu nifas yang mengalami ruptur / luka perineum di puskesmas desa wilayah kerja Turi Lamongan sebanyak 30 responden. Pengumpulan data kebersihan vulva dengan memberikan kuesioner kepada ibu postpartum, sedangkan waktu penyembuhan luka perineum menggunakan lembar observasi. Kemudian dilakukan uji tabulasi silang dan statistik peringkat Spearman. Hasil penelitian menunjukkan bahwa postpartum ibu yang kurang mampu dalam melakukan kebersihan vulva semuanya mengalami keterlambatan penyembuhan luka sebanyak 14 orang (100\%), sedangkan kemampuan kebersihan vulva sebagian besar mengalami penyembuhan luka lambat, sebanyak 7 orang $(63,64 \%)$. ), serta kemampuan vulva baik hygienenya semua mengalami penyembuhan luka yang cepat sebanyak 5 orang $(100 \%)$. Dari hasil uji statistik yang diperoleh $\rho$ Spearman rank count $(0,000<0,05)$, yang berarti ada pengaruh kemampuan kebersihan vulva terhadap waktu penyembuhan luka perineum pada ibu nifas.
\end{abstract}

Kata Kunci: Kemampuan Kebersihan Vulva, Waktu Penyembuhan Luka, Post Partum

\section{ABSTRACT}

Vulva hygiene (care perineum) is action to clean and nourish the pubic arealfemininity in women especially postpartum perineal injuries. The purpose of this study was to investigate the effect of a mother's ability to hygiene vulva against time postpartum perineal wound healing. This research used a method correlation study, the design of a prospective longitudinal study (cohort). The samples were all postpartum mothers who suffered rupture/perineal wound in the village health center Geger working area Turi Lamongan as many as 30 respondents. Data collected vulva hygiene by giving questionnaires to mothers postpartum, whereas perineal wound healing time was collected using observation sheet. Then cross-tabulated and statistical test Spearman rank. The results showed that maternal postpartum less capable in performing vulvar hygiene are all experiencing delays wound healing as many as 14 people (100\%), while the ability of the vulva hygiene pretty largely experiencing slow wound healing, as many as 7 people (63.64\%), as well as the ability vulva good hygiene all experienced rapid healing of wounds as many as 5 people $(100 \%)$. From the statistical test results obtained $\rho$ Spearman rank count $(0.000<$ 0.05), which means there is the influence of vulvar hygiene capability to perineal wound healing time in the post-partum mothers.

Keywords : Ability Vulva Hygiene, Wound Healing Time, Post Partum Mothers 


\section{PENDAHULUAN}

Masa nifas adalah waktu yang akan dilalui oleh seorang perempuan pasca melahirkan bayinya serta akan mengalami proses pengembalian dan pemulihan organ reproduksinya sampai waktu enam minggu. Nama lain masa nifas yaitu post partum atau purperium, yaitu dimulai sejak waktu bayi dilahirkan kemudian placenta keluar dari uterus, sampai enam minggu kemudian, disertai dengan kembalinya organ yang berkaitan dengan kandungan seperti semula saat sebelum hamil, yang telah mengalami berbagai perubahan misal perlukaan karena proses melahirkan (Widyasih, dkk 2012).

Perubahan yang terjadi pada alat reproduksi baik interna maupun eksterna sedikit demi sedikit akan kembali pada keadaan semula seperti sebelum hamil, yang mana hal inidisebut dengan proses involusi. Menurut Bahiyatun (2009), perubahanperubahan yang terjadi pada saat involusi yaitu hemokonsentrasi dan timbulnya laktasi yang dipengaruhi oleh laktogenik hormone dari kelenjar hipofisis terhadap mammae.

Sementara menurut Reeder
(2011) berpikir bahwa selain
perubahan-perubahan di atas, perubahan yang lainnya juga terjadi pada uterus, bekas implantasi uri, luka pada jalan lahir, nyeri atau after pains, Lochea, serviks dan ligamen-ligamen.

Ibu post partum harus melakukan perawatan baik untuk dirinya atau pada bayinya. Perawatan dan tindakan yang harus dilakukan oleh ibu nifas diantaranya yaitu: Mobilisasi, nutrisi yang baik untuk membantu proses pemulihan organ-organ kandungannya, perawatan payudara, laktasi, perawatan perineum (vulva hygiene). Selain itu menurut Widyasih dkk (2012), juga menegaskan tentang hal-hal yang pasti dilakukan oleh ibu pasca bersalin misalnya: diet, miksi, defekasi, cuti hamil dan bersalin, pemeriksaan pasca persalinan, serta nasehat-nasehat pada ibu post partum. Luka pada perineum karena tindakan episiotomi atau robekan merupakan daerah yang tidak mudah dikendalikan dan dijaga agar tetap bersih dan kering.

Perawatan khusus sangat diperlukan agar daerah genetalia yang mengalami perlukaan bias sembuh dengan cepat tanpa komplikasi. Menurut Reeder (2011), tindakan menjaga kebersihan pada daerah perineum memberikan kesempatan untuk melakukan inspeksi secara 
seksama. Selain itu Bahiyatun (2009), juga menyebutkan bahwa perawatanyang bisa dilakukan oleh ibu post patum seperti mengganti pembalut sesering mungkin setiap kali mandi atau setiap 4 sampai 6 jam, melepas pembalut dari arah depan kebelakang untuk menghindari penyebaran bakteri dari daerah anus ke vagina, membersihkanluka perineum dengan air hangat, menganjurkan ibu untuk mencuci tangan dengan sabun dan air sebelum menyentuh daerah kelamin, anjurkan ibu untuk tidak menyentuhluka perineum sampai area tersebut pulih.

Berdasarkan studi awal di lingkup kerja Puskesmas Turi Lamongan, pada bulan Mei 2017. Terdapat 10 orang ibu nifas yang mengalami luka perineum didapatkan data 6 orang yang tidak dapat melakukan vulva hygiene (perawatan perineum) dengan benar, seperti ibu baru mau mengganti pembalut jika pembalutnya sudah dirasa benar-benar basah atau penuh, ibu masih sering membersihkan luka jahitanya menggunakan ramuan-ramuan yang diberikan keluarga mereka. Hal tesebut memberikan bukti bahwa masih rendahnya kemampuan ibu dalam melakukan vulva hygiene secara benar.

Pada kasus ini kebanyakan ibu nifas yang mengalami luka perineum tidak melakukan vulva hygiene dengan benar dipengaruhi beberapa faktor, salah satu diantaranya yaitu sikap ibu nifas tersebut.Ibu merasa belum mampu melakukan Vulva Hygiene dengan benar.Hal ini dikarenakan perasan ibu yang takut jahitannya lepas jika sering ganti pembalut. Selain itu kurangnya pemberian informasi tentang vulva hygiene pada ibu nifas dapat mempengaruhi ibu dalam melakukan vulva hygiene secara benar.

Menurut Notoatmodjo (2012), sikap atau perilaku seseorang dalam berperilaku atau melakukan tindakan dipengaruhi oleh 2 faktor, yaitu faktor internal dan faktor eksternal. Faktor internal diantaranya yaitu: pendidikan, sikap, pengalaman dan informasi. Faktor eksternal yaitu: Konseling Interpersonal Edukatif (KIE) bidan dan sosial budaya. Jika ibu post partum tidak melakukan perawatan perineum (vulva hygiene) secara benar, maka akan berdampak pada luka jahitannya, yaitu lukanya akan rawan terkena infeksi. 
Tujuan penelitian yaitu menganalisis pengaruh kemampuan vulva hygiene terhadap waktu penyembuhan luka perineum pada ibu post partum.

\section{METODE PENELITIAN}

Metode penelitian yang digunakan mengadopsi pada teori Hidayat (2016) dan Suharsimi (2010). Jenis penelitian observasional dengan desain longitudinal yang bersifat prospektif (kohort), penelitian dilaksanakan pada bulan April-Juni 2017. Populasi dalam penelitian ini adalah semua ibu post partum yang mengalami rupture/luka perineum di Lingkup Kerja Puskesmas Turi, dengan rata-rata $33 \mathrm{ibu}$ post partum primipara yang mengalami luka perineum tiap 2 bulan. Dari perhitungan sampel penelitian ini adalah 30,4 yang dibulatkan menjadi $30 \mathrm{ibu}$ post partum yang mengalami luka perineum. Teknik pengumpulan data menggunakan kuesioner untuk vulva hygiene dan lembar observasi untuk penyembuhan luka perineum, kemudian untuk mengetahui adanya pengaruh vulva hygiene terhadap waktu penyembuhan luka perineum peneliti menggunakan uji spearman rank dengan $\alpha 0.05$.
HASIL DAN PEMBAHASAN

Gambaran Ibu yang Mengalami Luka Perineum Berdasarkan Usia Ibu

Hasil penelitian tentang gambaran jumlah ibu nifas yang mengalami luka perineum berdasarkan usia ibu.

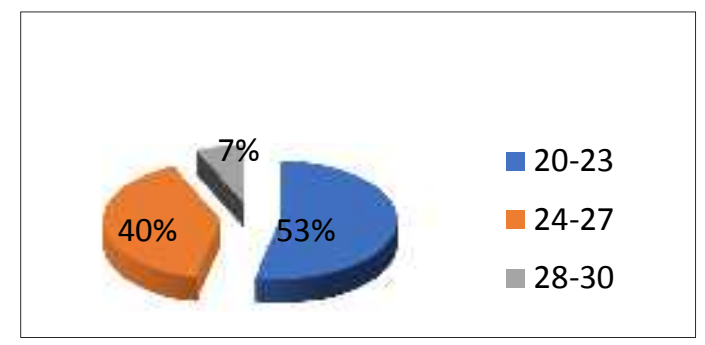

Gambar 1. Gambaran ibu post partum yang mengalami luka perineum berdasarkan usia ibu.

Dari Gambar 1 dapat digambarkan bahwa lebih dari setengah responden yang mengalami luka perineum berumur 20-23 tahun yaitu sejumlah 16 orang $(53 \%)$.

\section{Gambaran Ibu yang Mengalami Luka Perineum Berdasarkan Pendidikan Ibu}

Hasil penelitian tentang gambaran jumlah ibu nifas yang mengalami luka perineum berdasarkan pendidikan ibu. 


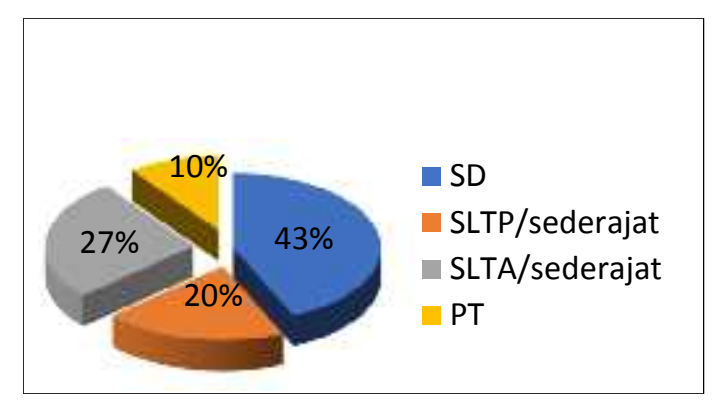

Gambar 2. Gambaran ibu post partum yang mengalami luka perineum berdasarkan pendidikan ibu.

Dari Gambar 2 tersebut dapat digambarkan bahwa kurang dari setengah responden yang mengalami luka perineum memiliki tingkat pendidikan SD yaitu sejumlah 13 orang $(43 \%)$.

\section{Gambaran Ibu yang Mengalami Luka Perineum Berdasarkan Pekerjaan Ibu}

Hasil penelitian tentang gambaran jumlah ibu nifas yang mengalami luka perineum berdasarkan pekerjaan ibu.

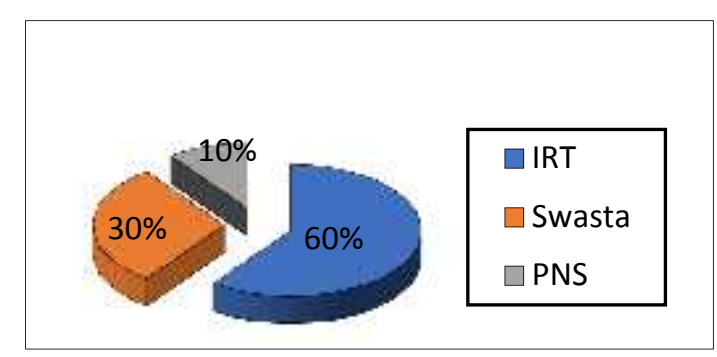

Gambar 3. Gambaran ibu post partum yang mengalami luka perineum berdasarkan pekerjaan ibu.

Dari Gambar 3 dapat digambarkan bahwa lebih dari setengah responden yang mengalami luka perineum mempunyai pekerjaan yaitu sebagai ibu rumah tangga sebanyak 18 orang $(60 \%)$.

Gambaran Kemampuan vulva hygiene pada ibu post partum yang mengalami luka perineum

Hasil penelitian tentang gambaran kemampuan ibu post partum yang mengalami luka perineum untuk melakukan vulva hygiene.

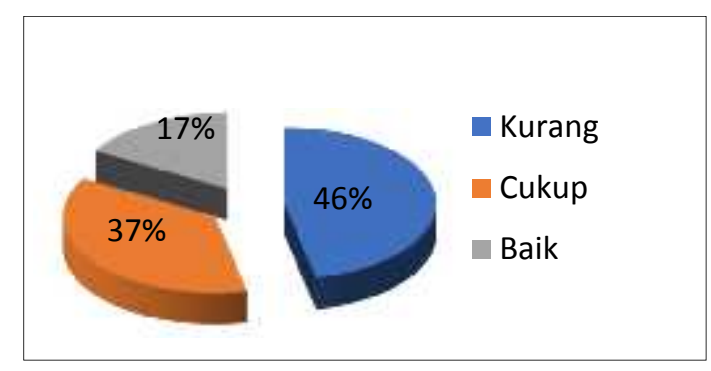

Gambar 4. Gambaran kemampuan ibu post partum yang mengalami luka perineum untuk melakukan vulva hygiene

Dari gambar 4 dapat digambarkan bahwa kurang dari setengah responden masih kurang mampu melakukan vulva hygienekurang yaitu sebanyak 14 orang (46\%).

Ibu post partum yang kemampuannya kurang dalam melakukan vulva hygiene kebanyakan dari mereka pada saat melakukan vulva hygiene jarang bahkan ada yang hampir tidak pernah mengompres luka jahitan dengan air hangat. Selain itu, 8 dari 14 ibu post partum (46\%) yang memiliki 
kemampuan vulva hygiene kurang, didapatkan bahwa mereka baru mau ganti pembalut kalau mereka sudah merasa pembalutnya benar-benar basah dan penuh. Kenyataan lainnya, terdapat 6 ibu post partum yang masih belum tahu bagaimana caranya melepas pembalut yang benar, serta masih ada juga yang menggunakan ramu-ramuan untuk membersihkan luka jahitannya.

Data yang diperoleh dari hasil penelitian menunjukkan bahwa ibu post partum yang kemampuannya kurang dalam melakukan vulva hygiene secara benar salah satunya disebabkan oleh status pendidikan ibu yang rendah yaitu SD sebanyak 13 orang (43\%). Ibu post partum yang berpendidikan rendah akan mempengaruhi pada tingkat pengetahuan yang diperoleh dan dimilikinya. Hal ini dikarenakan ibu dengan tingkat pendidikan rendah akan sulit menerima informasi kesehatan dan akan sulit merubah sikap dan perilaku mereka. Informasi ini yang juga menjadi salah satu faktor perubahan perilaku seseorang. Apabila informasi yang diperoleh dapat diterima secara akal ataupun bermanfaat, maka secara otomatis seseorang akan cenderung mengikuti dan menerapkan dari pemberian informasi tersebut. Hal ini dipertegas oleh Teori Snehandu B.Kar yang menyebutkan bahwa perilaku kesehatan seseorang atau masyarakat ditentukan oleh niat orang terhadap objek kesehatan, ada atau tidaknya dukungan dari masyarakat sekitar, ada atau tidaknya informasi tentang kesehatan, serta situasi yang memungkinkan seseorang itu untuk bertindak/berperilaku.

Data yang diperoleh dari hasil penelitian mayoritas ibu post partum memiliki pekerjaan sebagai ibu rumah tangga yaitu sebanyak 18 orang (60\%). Ibu post partum yang memiliki pekerjaan sebagai ibu rumah tangga juma bisa mempengaruhi pengetahuan yang dimiliki oleh ibu tentang vulva hygiene secara benar. Dimana ibu yang bekerja dirumah terdapat keterbatasan untuk memperoleh informasi kecuali jika ibu dengan ekonomi menengah ke atas bisa memperoleh informasi melalui handphone. Terkadang mereka belum mendapat informasi yang benar tentang cara vulva hygiene/perawatan luka perineum secara benar juga kurang dan terbatas, mereka kurang mendapatkan pengalaman dan informasi dari dunia luar. Ibu rumah tangga memiliki kegiatan yang hanya terbatas dalam rumah saja, dan kemungkinan untuk 
bertukar pikiran dan pengalaman dengan orang-orang di luar sangat terbatas, dalam hal ini cara melakukan perawatan luka perineum secara benar.

Gambaran waktu penyembuhan luka perineum pada ibu post partum yang mengalami luka perineum

Hasil penelitian tentang

Gambaran waktu penyembuhan luka perineum pada ibu post partum yang mengalami luka perineum.

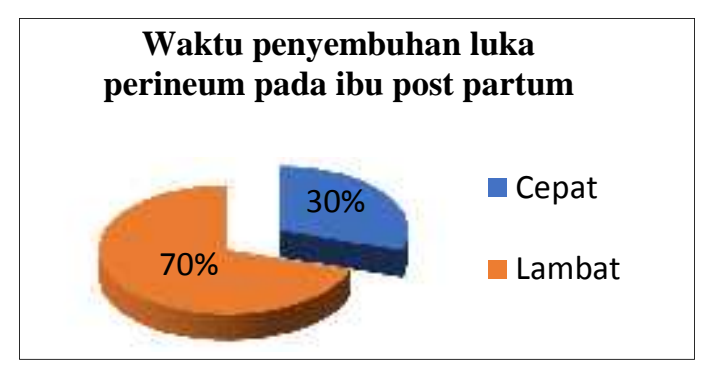

Gambar 5. Gambaran penyembuhan luka perieum pada ibu post partum

Dari Gambar 5 dapat digambarkan bahwa sebagian besar penyembuhan luka pada ibu post partum adalah lambat yaitu sebanyak 21 orang $(70 \%)$.

Data yang diperoleh dari hasil penelitian didapatkan bahwa ibu-ibu post partum yang penyembuhan luka perineumnya lambat salah satunya disebabkan oleh status pendidikan ibu yang rendah yaitu SD sebanyak 13 orang (43\%). Ibu-ibu yang berpendidikan rendah akan mempengaruhi tingkat pengetahuan yang diperoleh dan yang dimilikinya. Seperti yang dijelaskan oleh Notoatmodjo (2005), pendidikan merupakan segala upaya yang direncanakan untuk mempengaruhi orang lain sehingga mereka melakukan apa yang diharapkan oleh pelaku pendidikan. Ibu post partum yang tingkat pendidikan rendah kemungkinan memiliki tingkat pengetahuan yang kurang tentang perawatan pasca melahirkan sepertimobilisasi, eliminasi, nutrisi, personal hygiene dan vulva hygiene. Dimana nutrisi, mobilisasi, perawatan luka perineum maupun personal hygiene sangat mempengaruhi kecepatan penyembuhan luka.

Seperti yang dikemukakan oleh Morison (2004), dalam pembentukan jaringan diperlukan pemenuhan nutrisi yaitu diet kaya protein, karbohidrat, lemak. vitamin dan A, mineral seperti Fe dan $\mathrm{Zn}$. Pasien yang kurang nutrisi memerlukan waktu untuk memperbaiki status gizi mereka setelah pembedahan.

Di lain pihak, ada 9 ibu post partum (30 \%) yang mengalami penyembuhan luka perineumnya secara cepat. Hal ini dikarenakan sebagian besar dari mereka sudah mempunyai kemampuan yang cukup dan baik dalam 
melakukan perawatan luka perineum/vulva hygiene. Salah satunya disebabkan oleh status tingkat pendidikan ibu, yang mana pada ibu yang memiliki kemampuan vulva hygiene baik dan cukup, sebagian dari mereka memiliki status status pendidikan sedang yaitu SMA sebanyak 8 orang $(26,67 \%)$, dan ada juga yang tingkat pendidikannya tinggi yaitu sebanyak 3 orang $(10 \%)$. Tingkat pendidikan ini akan mempengaruhi tingkat pengetahuan seseorang. Apabila seorang ibu post partum memiliki tingkat pendidikan tinggi, maka kemungkinan pengetahuannya tentang sesuatu hal akan lebih baik, dalam hal ini hubungannya dengan vulva hygiene/perawatan luka perineum.

Seperti yang telah dikemukakan oleh Notoatmodjo (2005), pendidikan merupakan segala upaya yang direncanakan untuk mempengaruhi orang lain baik individu, kelompok atau masyarakat, sehingga mereka melakukan apa yang diharapkan oleh pelaku pendidikan. Selain faktor pendidikan, faktor umur juga mempengaruhi waktu penyembuhan luka perineum seseorang. Selain faktor pendidikan, faktor umur juga mempengaruhi waktu penyembuhan luka perineum seseorang.

Berdasarkan hasil penelitian, didapatkan ibu-ibu post partum yang memiliki umur muda yaitu umur 20-23 sebanyak 16 orang (53\%). Pada ibu yang memiliki umur muda, penyembuhan lukanya relatif cepat, hal ini dikarenakan proses regenerasi jaringan yang rusak akan cepat terganti oleh jaringan yang baru. Sedangkan pada orang yang memiliki umur tua telah terjadi penurunan dari fungsi tubuh dalam melakukan proses regenerasi. Sehingga proses penyembuhan lukanya akan lebih lambat.

Hal ini juga diperkuat oleh pernyataan Morison (2004), yang menyebutkan bahwa sistem tubuh yang berbeda "tumbuh" dengan kecepatan yang berbeda pula, tetapi lebih dari usia 30 tahun mulai terjadi penurunan yang signifikan dalam beberapa fungsinya, seperti penurunan efisiensi jantung, dan penurunan efisiensi sisitem imun. Dalam hal ini, masing-masing masalah tersebut ikut mendukung terjadinya keterlambatan penyembuhan seiring dengan bertambahnya usia. 

Tabulasi silang pengaruh kemampuan vulva hygiene terhadap waktu
penyembuhan luka perineum pada ibu post partum primipara

Tabel 1. Pengaruh kemampuan vulva hygiene terhadap waktu penyembuhan luka perineum pada ibu post partum primipara

$$
\begin{array}{ccc}
\multicolumn{2}{c}{\text { Penyembuhan luka }} & \text { Total } \\
\text { Lambat } & \text { Cepat }
\end{array}
$$

Kemampuan vulva hygiene

\begin{tabular}{lcccccc} 
& $\mathrm{Jml}(\mathrm{n})$ & $(\%)$ & $\begin{array}{c}\mathrm{Jml} \\
(\mathrm{n})\end{array}$ & $(\%)$ & $\mathrm{Jml}(\mathrm{n})$ & $(\%)$ \\
\hline Kurang & 14 & 100 & 0 & 0 & 14 & 100 \\
Cukup & 7 & 63,64 & 4 & 36,36 & 11 & 100 \\
Baik & 0 & 0 & 5 & 100 & 5 & 100 \\
Uji Statistik & & \multicolumn{5}{c}{0,05} \\
Spearman rank Test & \multicolumn{7}{c}{ Value: 0,000} \\
\hline
\end{tabular}

Dari hasil tabulasi silang tersebut menunjukkan bahwa ibu post partum yang kemampuannya kurang dalam melaksanakan vulva hygiene semuanya mengalami keterlambatan penyembuhan luka yaitu sebanyak 14 orang (100\%), sedangkan yang kemampuan vulva hygienenya cukup lebih dari setengah responden mengalami penyembuhan luka yang lambat yaitu sebanyak 7 orang $(63,64$ $\%)$, serta yang kemampuan vulva hygienenya baik semuanya mengalami penyembuhan luka cepat yaitu sebanyak 5 orang (100\%). Setelah dilakukan uji Spearman rankdengan $\quad \alpha \quad 0,05$ menggunakan SPSS didapatkan hasil $\rho$ Value < 0,05 hal ini berarti H0 ditolak/Ha diterima, artinya ada pengaruh kemampuan vulva hygiene terhadap waktu penyembuhan luka perineum pada ibu post partum.

Ibu post partum yang mengalami keterlambatan dalam penyembuhan lukanya rata-rata masih merasakan kesakitan dan nyeri pada luka perineumnya serta lukanya masih kelihatan bengkak. Dalam hal ini sangat erat hubungannya dengan bagaimana cara ibu dalam melakukan perawatan luka perineum. Apabila seseorang tidak mampu atau bahkan tidak mau melakukan vulva hygiene/perawatan luka perineum secara benar, seperti ibu tidak mau mengompres luka jahitan dengan air hangat yang mana hal ini membantu dalam proses penyembuhan luka perineum. Seperti yang telah dijelaskan oleh Bahiyatun (2009), salah satu perawatan luka perineum adalah berendam air hangat atau kompres 
dengan air hangat, yang mana hal itu membantu pelebaran/vasodilatasi pembuluh darah yang kemudian membantu sirkulasi dan meningkatkan ketersediaan $\mathrm{O}_{2}$ ke luka perineum, maka secara otomatis fisioligis penyembuhan luka perineum akan terganggu atau akan lebih lambat.

Menjaga luka perineum tetap kering dan bersih juga membantu fisiologis penyembuhan luka perineum. Dengan menjaga perineum tetap bersih dan kering, maka akan menghilangkan reservoir bagi pertumbuhan mikroorganisme, sehingga infeksi dapat dicegah. Infeksi juga dapat dicegah dengan cara tidak memegang luka perineum sampai luka kering. Hal ini dikarenakan tangan kita yang belum tentu bersih membawa mikroorganisme yang bisa menyebabkan terjadinya infeksi, dan infeksi ini yang akan menghambat penyembuhan luka perineum. Tetapi apabila kita mau memegang atau mau menyentuh daerah kelamin, maka sebelumnya kita harus mencuci tangan menggunakan sabun dan air bersih yang mengalir terlebih dahulu. Seperti yang telah dikemukakan oleh Morison (2004), infeksi luka dapat menghambat penyembuhan luka, dan bakteri sebagai sumber penyebab infeksi.

Perawatan luka perineum yang lainnya adalah ketika kita selesai buang air besar dan buang air kecil, hendaknya kita membersihkan vagina dengan air hangat. Tindakan ini memiliki manfaat yang sama dengan tindakan mengompres luka perineum dengan air hangat yaitu memvasodilatasi pembuluh darah sehingga sirkulasi darah ke luka meningkat.

Apabila seseorang tidak melakukan vulva hygiene/perawatan luka perineum secara benar, maka akan mengakibatkan pada penyembuhan lukanya yang akan menjadi lambat. Hal ini terjadi pada ibu post partum yang memiliki kemampuan kurang dalam melakukan vulva hygiene/perawatan luka perineum secara benar.

Apabila seorang ibu yang mengalami luka perineum tidak melakukan vulva hygiene/perawatan luka perineum secara tidak tepat, maka hal ini akan mengakibatkan pada lukanya yang rentan terhadap infeksi dan berpengaruh pada waktu penyembuhan lukanya.

Hal ini diperkuat pendapat Morison (2004), yang menyebutkan bahwa perawatan luka secara benar 
mempunyai pengaruh penting dalam proses penyembuhan luka tersebut, khususnya pada ibu yang mengalami luka perineum.

Perawatan luka berfungsi untuk membunuh atau mencegah bakteri masuk ke dalam luka. Jika luka sudah bebas dari bakteri, maka kemungkinan penyembuhan luka akan cepat. Selain itu Morison juga menyebutkan bahwa melalui proses regenerasi akan mengakibatkan pergantian jaringan yang telah rusak atau mati dengan jaringan yang baru. Luka dikatakan sembuh apabila permukaannya bersatu kembali dan didapatkan kekuatan jaringan sudah mencapai normal.

Di lain pihak (Mawardi, 2002) berpendapat bahwa penyembuhan luka ada dua kategori.Pertama, pemulihan jaringan adalah regenerasi jaringan pulih seperti semula, baik struktur maupun fungsinya. Kedua, repair yaitu pemulihan atau penggantian oleh jaringan ikat.

\section{SIMPULAN DAN SARAN}

Berdasarkan hasil penelitian dan pembahasan melalui analisa data pengaruh kemampuan vulva hygiene terhadap waktu penyembuhan luka perineum dapat disimpulkan bahwa kemampuan vulva hygiene pada ibu post partum primipara di Desa Geger Lingkup Kerja Puskesmas Turi Lamongan sebagian besar masih kurang.Waktu penyembuhan luka perineum pada ibu post partum primipara di Desa Geger Wilayah Kerja Puskesmas Turi Lamongan sebagian besar lambat/tidak sesuai waktu.Ada pengaruh kemampuan vulva hygiene terhadap waktu penyembuhan luka perineum pada ibu post partum primipara di desa Geger wilayah kerja puskesmas Turi Lamongan.

Sehingga perlu peran aktif ibu untuk mendapatkan informasi dengan membaca dari buku ataupun majalah tentang bagaimana cara melakukan perawatan perineum. Selain itu diharapkan petugas kesehatan dapat memberikan informasi yang rutin, cukup dan lengkap tentang pentingnya perawatan luka perineum secara benar.

\section{DAFTAR PUSTAKA}

Alimul, Aziz. 2005. Kebutuhan Dasar Manusia. Jakarta: EGC.

2010. Metode Penelitian Kebidanan Teknik analisa Data. Jakarta: Salemba Medika.

Arikunto, Suharsimi. 2006. Prosedur Penelitian Suatu Pendekatan Praktik. Jakarta: Rineka Cipta. 
Bahiyatun. 2009. Buku Ajar Asuhan

Kebidanan Nifas Normal.

Jakarta: EGC.

Farrer, Helen. 2001. Perawatan Maternitas. Jakarta: EGC.

Morison, Moya. 2004. Manajemen Luka. Jakarta: EGC.

Notoatmodjo, Soekidjo. 2003. Pendidikan dan Perilaku Kesehatan. Jakarta: Rineka Cipta. . 2007. Promosi Kesehatan dan Ilmu Perilaku. Jakarta: Rineka Cipta. . 2005. Metodologi Penelitian Kesehatan. Jakarta: Rineka Cipta.

Nursalam, Pariani. 2001. Pendekatan Praktis Metodologi Riset Keperawatan. Jakarta: Salemba Medika.

Reiss, Uzzi. 2008. Menjadi Ibu Bahagia Pasca Persalinan. Jogjakarta: Luna Publisher.

Salmah. 2006. Asuhan Kebidanan Antenatal. Jakarta: EGC. 